\title{
Museology teaching departments in Sweden have been evaluated
}

JANNE VILKUNA*

\begin{abstract}
This article discusses the activities and impact of the Swedish National Agency for Higher Education (Högskoleverket) and the two evaluations of Swedish museology that this body has carried out.
\end{abstract}

Key words: Evaluation, museology, museum studies, examination right.

\section{AN ORGANIZATION FOR HIGHER EDUCATION}

In the museum world, Sweden has been a spearhead country, with important innovations conducted during both the 20th and 21st centuries by men like Artur Hazelius and Gustaf Kolthoff, and the setting up of organizations for contemporary museum collecting and documentation (Samdok) and travelling exhibitions (Riksutställningar). The country was also a museological trail-blazer, with university studies in museology available at Umeå University in 1981.

Sweden also harmonized its universities at an early stage by founding the University Counsellor Office (Universitetskanslerämbetet, $U K \ddot{A})$ in 1964 . The task of this body was to plan, co-ordinate and monitor all Swedish universities. The country got its first University Act thirteen years later, thereby increasing the degree of uniformity between the different Swedish universities.

At the same time, the University Counsel- lor Office was reorganized into the University Office (Universitets- och högskoleämbetet, UḦ̈). This central office was disbanded in 1992 and replaced with six new offices. By 1995, however, it was already apparent that the Swedish universities still needed a central office, and the Swedish National Agency for Higher Education (Högskoleverket, HSV) was therefore established.

One of the main tasks of this agency became reviewing the quality of higher education in Sweden. This is carried out by an international expert group reviewing certain subjects at the same time in all the universities at which these are studied. If an university does not pass this audit, it is given a limited time to comply with the appropriate requirements. If it is unable to do so, the university in question forfeits the right to conduct examinations in this subject.

Once the review has been completed and approved by the agency, the executive body sends its decision to the principal of the uni- 
142 versity in question. This is done shortly before the decision is published so the principal can prepare his/her comments about the situation to the general public and the media.

\section{THE FIRST AUDIT}

In 2003-2004, the MBA subjects were reviewed. This meant that the departments of museologies or museum studies at the universities of Gothenburg, Uppsala and Umeå were evaluated by visiting each department.

The reviewer group consisted of Ms Elisabet Olofsson, Executive Director of the Swedish-African Museum Programme (SAMP), Mr Janne Vilkuna, Professor of Museology at Jyväskylä University, Finland (the author of this article) and three students of museology (one from each of the universities undergoing this form of audit): Ms Karin Tångeberg from Uppsala University, Mr Bengt Wittgren, doctoral student from Umeå University and Mrs Irén Wängnerud from Gothenburg University. Naturally, the student members stood down when the group audited their own university. The group was joined and supported by officials from the Swedish National Agency for Higher Education.

During the local visits, hearings were conducted with both the administrators and with teachers and students.

The report was published in 2004 (Utvärdering av ämnena arkivvetenskap, biblioteksoch informationsvetenskap, bok-och bibliotekshistoria, informations- och medievetenskap, kulturvard och museologi vid svenska universitet och högskolor Rapportserie 2004:27 R http://www. hsv.se/download/18.539a949110f3d5914ec8 00093667/0427R.pdf).

Although the problem in all the departments was - and still is - the quite limited permanent personnel resources, all departments cleared the review. However, each was given specific recommendations.

Furthermore, five recommendations were made that were common to all the departments, as follows:

- Develop contacts with employers both in Sweden and Europe.

- Begin a shared process for museology in Sweden, in the spirit of the Bologna Treaty.

- Benefit from each others' teacher resources and co-operate with visiting lecturers, etc.

- Develop networks and methods by increasing intakes of students from subjects other than the arts, e.g. science and technology.

- Co-operate with museological research projects, where professors, lecturers and doctoral students contribute. It would be beneficial if these projects incorporate a practical point of view, i.e. are carried out in collaboration with museums or similar participants.

\section{THE SECOND AUDIT}

Ms Olofsson and I were somewhat surprised when the Swedish National Agency for Higher Education contacted us again in 2008 and asked if we could again review museology departments in a new MBA subject auditing. The reason for a new audit being carried out so soon was that in 2007 Sweden had introduced the European two-step system of degrees, in accordance with the Bologna Treaty. New knowledge about the situation was now needed.

Before introducing the Bologna-style MA, Sweden had a lower master examination ( $m a-$ gisterexamen) that in practical terms meant one year of studies after completing a BA (kandidatexamen). Students who have not finished their examination before 1st July 2007 
can still take the Swedish master examination until 2015.

The task was to write a national description of the subjects with the help of hard and soft data that the agency had collected from the universities.

When the report was ready, it was published in December 2008 (Granskning av utbildningar inom kulturvaird och $A B M$-området 2008:45 R http://www.hsv.se/download/18.12 584b1911e21a5c9d57ffe449/0845R.pdf). At the same time, it was decided to continue the auditing process in 2009 with a deeper evaluation, by visits to the departments in question (Decision: http://www.hsv.se/download/18. 12584b1911e21a5c9d57ffe713/643-376207+Kulturv\%C3\%A5rd+och+ABM.pdf). The group was now joined by museology student Ms Nana Mikkelsen from Aarhus University, Denmark.

The audit involved criteria featuring many different aspects. However, the most important new ones were - firstly - the requirement of a close relation to a research environment and - secondly - the minimum requirements regarding the qualifications of permanent academic personnel for teaching at BA, MA and $\mathrm{PhD}$ levels. The minimum at all these levels is for two PhDs: at the BA level, two PhDs; at the lower master level, one must be a Phd and the other must be an Adjunct Professor (Docent); at the MA level both must be Adjunct Professors; and at the PhD level one must be an Adjunct Professor and the other a Professor.

On the grounds of the finished report, the senior executive of the Agency gave her decision on 19th May 2009. The examination rights associated with the MA and Swedish master degrees at the International Museum Studies at Gothenburg University and the $\mathrm{Mu}$ - seum and Cultural Heritage Science (musei- och kulturarvsvetenskap) at Uppsala University were questioned, and the institutions concerned were ordered to report by 19th May 2010 on what actions had been carried out to rectify this situation. After this, the Agency will decide whether or not there continues to be a need to withdraw the right to conduct examinations (Decision: http://www.hsv.se/download/18.1 dbd1f9a120d72e05717ffe2282/643-3762$07+$ arkiv+museologi.pdf).

\section{A HARD FACT}

Finland does not have an corresponding evaluation body. If comparable minimum criteria of teaching personnel were to be applied, not a single museology department at the five Finnish universities would be granted the right to conduct examinations. The situation is very similar in other Nordic countries.

This is the reason why I regard the Swedish National Agency for Higher Education very highly. It forces the principals of the universities to at least adhere to minimum standards that ensure even the smallest subjects have realistic opportunities to develop, in terms of both research and teaching.

* Mr. Janne Vilkuna is Professor of Museology and the Director of the University Museum at Jyväskylä University, Finland.

Address: Museology, P.O. Box 35 (G), FIN-40014 Jyväskylä University

E-mail: janne.vilkuna@jyu.fi 